The EU's Trifecta Mechanisms: Analysis of EU's Response to the Challenges to the Rule of Law and Corruption

Author(s): Stoyan Panov

Source: Kyiv-Mohyla Law and Politics Journal 5 (2019): 83-117

Published by: National University of Kyiv-Mohyla Academy

http://kmlpj.ukma.edu.ua/ 


\title{
The EU's Trifecta Mechanisms: Analysis of EU's Response to the Challenges to the Rule of Law and Corruption
}

\author{
Stoyan Panov \\ University College Freiburg \\ Albert-Ludwigs Universität Freiburg
}

\begin{abstract}
The following paper examines the envisaged framework and effectiveness of the triangulation of mechanisms currently planned at the EU level: the establishment of the European Public Prosecutor's Office (EPPO), proceedings under Article 7 of the Treaty on European Union (TEU) against Poland and Hungary, and the mechanism to protect EU's budget in deficiencies with regards to the rule of law in Member States. This research focuses on the overall structure and powers of the EPPO with special attention on its role in investigating and prosecuting offences affecting to the EU's financial interests. This includes active and passive corruption among others with particular emphasis on the expected interaction between the EPPO and the national authorities. However, not all EU Member States have joined the EPPO framework. Here the role of the EU institutions is analyzed in light of the recent developments in Article 7 TEU proceedings. A third possible mechanism to react to the growth of executive powers in some states and the corresponding imbalances is the EU Commission's proposal for a mechanism on the protection of the EU's budget in case of generalized deficiencies as regards the rule of law. This may include corruption or other breaches to the implementation of the Union budget.
\end{abstract}

Key Words: European Public Prosecutor's Office, Article 7 TEU, Deficiencies in Rule of Law, Anti-corruption, Judicial Review, EU funds

\section{7)}

\section{Introduction}

Article 2 TEU stipulates that the EU "is founded on the values of respect for human dignity, freedom, democracy, equality, the rule of law and respect for human rights, including the rights of persons belonging to minorities." This language echoes a hierarchy of norms, embedded in what resembles a process of EU's constitutionalization. ${ }^{1}$ The EU is a supranational order, shaped by common values and expectations, rules, procedures and clearly defined sanctions. In this manner, the "constitution" aspect of the Union is a limitation of other powers through law, in a paradigm or legal order

$1 \quad$ See Joseph Weiler and Marlene Wind, European Constitutionalism beyond the State (Cambridge: Cambridge University Press, 2003). 
"with the aim of furthering a normative agenda of...integration and legal control of politics." 2 The intersection of law and politics is clearly discernible in hierarchical or vertical arrangements of constitutionalizing powers at domestic, supranational or international orders as "law is the product of political activity, which has been fixed in order to organize and limit political action." ${ }^{3}$ The contestation of values and priorities of organizations, states and individuals may become a character of an order in which the applicability and examination of the rule of law as an essential element "can be seen as the continuation of politics by other means." 4 This is particularly relevant for circumstances in which the intersection of politics and law could give rise to acts of corruption, as seen below. The importance of mechanisms with the purpose to respond to corruption and maintain the rule of law becomes even more pertinent when the legal order is complex and multilayered as is the structure of the EU.

The recent backsliding in the rule of law in some Central and Eastern European States such as Hungary, Poland and Romania has coincided with the renewed efforts on part of the EU institutions to create mechanisms to respond to deficiencies of the rule of law and to protect the financial interests of the Union. This paper aims to examine three such mechanisms. The first part analyzes the broadest mechanism under Article 7 TEU with concrete examples of Hungary and Poland. The Article 7 TEU proceedings are examined in light of the EU institutions engaged in the decision-making process. The second part is dedicated to the European Public Prosecutor's Office (EPPO). The EPPO is analyzed through an overview of its competences and structure. The part contains a detailed analysis of the judicial review framework of acts or omissions of the EPPO as the function of the EPPO directly affects individuals or legal entities in the EU. The final section of the paper looks at the proposal for sanctions in cases of deficiencies of the rule of law in EU Member States. The proposal is evaluated in light of its function and relevant actors. Some problems are outlined as regards the potential suspensions of EU funds to the sanctioned state(s). In this manner, the paper aims to analyze three different but intersecting mechanisms: from the most intergovernmental Article 7 TEU proceedings through the more specific, criminal law-oriented EPPO that is soon to be functioning to the planned framework of the suspension of EU funds in cases of deficiencies of the rule of law.

\section{Article 7 TEU Proceedings}

The article commences with the Article 7 TEU mechanism as an example of an existing EU framework. The focus of the analysis is on the structure of the Article 7

2 Wouter Werner, "The Never-Ending Closure: Constitutionalism and International Law" in Transnational Constitutionalism: International and European Perspectives, ed. Nicholas Tsagouris (Cambridge: Cambridge University Press, 2007), 330. International Norms and Structures," Leiden Journal of International Law 19 (January 2006): 6o9. Andrea Bianchi, International Law Theories (Oxford: Oxford University Press, 2016), $5^{2 .}$ 
TEU mechanism as well as some problems with its (non-) use. Article 7 TEU creates a framework for ensuring that EU Member States respect the common values of the EU through a preventive mechanism under Article $7(1)$ TEU and a sanctioning mechanism under Article 7(2) TEU. The values enshrined in Article 2 TEU are foundational for the EU legal order and are considered to be at the top of the hierarchy of EU norms. ${ }^{5}$ The debate on what the Union could do against the backsliding of democracy and breaches of the fundamental values goes back to the accession process of Greece in the late 1970s. ${ }^{6}$ The contemporary origins of the Article 7 TEU mechanism could be found in the work of a Reflection Group in 1995 in the course of the preparation of the Amsterdam Treaty. The teleological function of the mechanism could be traced back to two primary issues of concern in the late 199os: the eventual enlargement of the Union with Central and Eastern Europe states with different political and legal traditions, and the recurring push for protection of fundamental values and human rights on a Union level. ${ }^{7}$

One of the most significant moments for the development and eventual nonuse of Article 7 TEU is the situation in Austria in 2000 with Haider and the Austrian Freedom Party (FPÖ) entering the coalition government. Although the response by the EU Member States was bilateral in terms of sanctions against Austria, the situation created the opportunity for a debate as to the introduction of a preventive mechanism respectively under the Nice Treaty and the Lisbon Treaty. ${ }^{8}$ In this manner, the purpose of Article 7 TEU has solidified as a mechanism of protection of the fundamental values of the Union from intra-EU threats originating from the political and legal conditions in the Member States. Article 7 TEU could be envisaged as a passerelle between the presumption that the values of Article 2 TEU would be followed in all Member States and the insurance against a breach of these fundamental values. ${ }^{9}$

The Article 7 TEU mechanism provides for the most Member State-oriented approach and for the most stringent potential sanctions. The preventive mechanism in case of "a clear risk of serious breach" offers the competence of the Council to "warn" the infringing Member States, while the sanctioning mechanism allows the Council to suspend certain rights of the Member State, including voting rights, in case of "a serious and persistent breach" of EU values.

Allan Rosas and Lorna Armati, EU Constitutional Law: An Introduction (Bloomsbury: Hart 2012), $53-55$.

Dimitry Kochenov, "Busting the Myths Nuclear: A Commentary on Article 7 TEU," EUI Working Papers Law 2017/10 (2017): 4-5.

See Wojciech Sadurski, "Adding a Bite to a Bark? A Story of Article 7, the EU Enlargement and Jörg Haider" Columbia Journal of European Law16 (2010): 386-87. See also, Reflection Group's Report, “A Strategy for Europe" Doc/95/8 (Messina, Brussels, June 2, 1995- December 5, 1995). See also, Laurent Pech, "'A Union Founded on the Rule of Law': Meaning and Reality of the Rule of Law as a Constitutional Principle of EU Law" EU Constitutional Law Review 6 (2010): 359.

8 Sadurski, "Adding a Bite to a Bark?" 409-13.

9 Dimitry Kochenov, "Busting the Myths Nuclear: A Commentary on Article 7 TEU," EUI Working Papers Law 2017/10 (2017): 4 . 
When examined carefully, the mechanism includes three distinct stages to safeguard the values of the EU:

1) a procedure to determine and declare a "clear risk of a serious breach" of the values enshrined in Article 2 TEU and the corresponding recommendation on remedying the situation under Article 7(1) TEU;

2) a mechanism to determine the existence of a serious and persistent breach of Union values under Article 7(2) TEU; and

3) a sanctioning procedure upon finding of a serious and persistent breach under Article 7(3) TEU.

The scope of application of Article 7 is broad, as the mechanism "seeks to secure respect for the conditions of Union membership. There would be something paradoxical about confining the Union's possibilities of action to the areas covered by Union law and asking it to ignore serious breaches in areas of national jurisdiction. If a Member State breaches the fundamental values in a manner sufficiently serious to be caught by Article 7 TEU, this is likely to undermine the very foundations of the Union."10 Nothing in the text of Article 7 TEU indicates that the three steps should be followed consequently. To the contrary, an Article 7(2) TEU procedure can be started without the commencement of a warning mechanism under Article 7(1) TEU.11

\section{Preventive Mechanism for Clear Risk of a Serious Breach under Article 7(1) TEU}

The preventive mechanism under Article 7(1) TEU aims to determine a clear risk of a serious breach of the Union values and to issue relevant remedial recommendations. It can be activated by several actors: The European Parliament, the Commission, or $1 / 3$ of the Member States. This procedure has the broadest array of actors who can initiate the preventive mechanism, indicating that it is to be considered the easiest to utilize. As the preventive procedure cannot lead to sanctions stricto sensu in comparison to Article $7(2-3)$ procedures, the purpose is to engage the EU institutions and the Member State in a dialogue in order to prevent the impending breach, which is another reason that explains the competence of multiple actors at this stage. ${ }^{12}$ The determination of a serious risk of a breach and an adoption of recommendations to the concerned Member State require a $4 / 5$ majority of the Council, excluding the concerned Member State(s), with the consent of the European Parliament. Such a high threshold in the determination process indicates the central role of the interests of the Member States in retaining and finding a common solution or lack of such to the serious risk of a breach. It resembles a traditional approach towards dispute resolution by constitutive members of the supranational organization.

10 European Commission, "Article 7 of the Treaty on European Union-Respect for and Promotion of the Values on which the Union is Based" $\operatorname{COM}(2003) 606$ final, 5 .

11 Dimitry Kochenov, "Busting the Myths Nuclear: A Commentary on Article 7 TEU," EUI Working Papers Law 2017/10 (2017): 6. 
Even before a reasoned proposal under Article 7(1) for a Council Decision is implemented, the Commission has used another auxiliary tool, the "Rule of Law Mechanism," since 2014, which serves as a non-binding framework to assess and prepare the Article 7(1) and 7(2) TEU procedures..$^{13}$ The Rule of Law Mechanism includes various recommendations on part of the Commission and replies by the concerned Member State as a process of dialogue before triggering the Article 7 TEU mechanism in order to determine the threat of a serious breach of the Article 2 TEU values. ${ }^{14}$ The Rule of Law Mechanism is applicable whenever the national authorities tolerate situations, likely to systematically and adversely affect the rule of law. ${ }^{15}$

The European Parliament has also been active in its attempt to link the Rule of Law Mechanism with the creation of an inter-institutional comprehensive Pact which focuses on the protection of the EU's budget in cases of generalized deficiencies in the rule of law in Member States, including inter alia "previous EU Anti-Corruption reports and the 2018 European Semester country reports point to serious concerns as regards corruption in various Member States, thereby eroding citizens' trust in institutions and the rule of law." 16 The proposed DRF scoreboard mechanism would include "an annual evidence-based and non-discriminatory review assessing, on an equal footing, all EU Member States' compliance with the values stipulated in Article 2 TEU" and aims to replace such existing special mechanisms dealing with corruption as the Cooperation and Verification Mechanism for Bulgaria and Romania. ${ }^{17}$

The first time that the Commission triggered the Article 7(1) TEU procedure, resulting in a proposal for a Council Decision was in 2017 in the situation concerning the rule of law in Poland. As a result of the October 25, 2015 General Elections and the majority secured by the Law and Justice Party (PiS) in the Sejm and Senate, the Law on the Supreme Court was amended to introduce the novelty of extraordinary judicial review of final and binding judgments. ${ }^{18}$ The Supreme Court could overturn completely or in part any final judgment delivered by Polish courts in the past 20 years in a period

13 European Commission, "A New EU Framework to Strengthen the Rule of Law" COM(2014)158.

14 For criticism, see Dimitry Kochenov and Laurent Pech, "Better Late than Never? On the European Commission's Rule of Law Framework and its First Activation," Journal of Common Market Studies 54, no. 5 (2016): 1062-74.

"Establishing of an EU Mechanism on Democracy, the Rule of Law and Fundamental Rights," European Parliament, accessed June 6, 2019, http://www.europarl.europa.eu/legislative-train/ theme-area-of-justice-and-fundamental-rights/file-eu-mechanism-on-democracy-the-rule-oflaw-and-fundamental-rights.

16 European Parliament, "Resolution Of November 14, 2018 On the Need for A Comprehensive EU Mechanism for the Protection of Democracy, The Rule Of Law And Fundamental Rights," 2018/2886(RSP) (November 14, 2018), point N. Id points 3 and 4. See also, Stoyan Panov, "Judicial Anti-Corruption Reforms in Bulgaria and the Rule of the EU in Bulgaria's Judiciary Regulation," Südosteuropa 61, no. 2 (2013), 193-218.

18 Article 89(1) of Law on the Supreme Court. 
of three year after entry into force of the Law on the Supreme Court. ${ }^{19}$ Overall, the extraordinary procedure introduced in the Polish legal order offers a systemic clash with the principle of resjudicata as "in order to ensure both stability of the law and legal relations and the sound administration of justice, it is important that judicial decisions which have become definitive after all rights of appeal have been exhausted or after expiry of the time-limits provided for in that connection can no longer be called in question." ${ }^{20}$ In December 2017, the European Commission issued a reasoned Proposal in Accordance with Article 7(1) of the Treaty on European Union regarding the Rule of Law in Poland focusing on the lack of an independent and legitimate constitutional review and the adoption by the Polish Parliament of new legislation relating to the Polish judiciary which raises grave concerns as regards judicial independence and increases significantly the systemic threat to the rule of law in Poland, in particular the Law on the Supreme Court and the restructuring and re-composition of the Constitutional Tribunal. ${ }^{21}$

The European Parliament triggered the Article 7(1) TEU procedure in the case of Hungary in 2018. After Fidesz won the 2010 general elections with two-thirds majority in the Hungarian National Assembly, the government focused on restructuring the constitutional order of Hungary with the adoption of a new Constitution (the Fundamental Law) and amendments of more than 6oo laws. The effect of this prolific legislative activity has been particularly felt in the judiciary as regards the independence of the judiciary, the termination of the mandates of a high number of senior judges as well as the replacement of the Hungarian Supreme Court's President..22

19 See Articles 89(4) and 115 of Law on the Supreme Court. There are certain restriction on the ability to overturn criminal cases to the detriment of the defendant, divorce cases, adoption decisions, petty offences and minor tax offences. See Article 9o(3-4) of Law on the Supreme Court.

$20 \quad$ Case C-224/o1 Gerhard Köblerv. Republik Österreich [2003] ECR I-10239, para 38.

21 Commission, 'Reasoned Proposal in Accordance with Article 7(1) of the Treaty on European Union regarding the Rule of Law in Poland' Com (2017) 835 final. The Commission outlines the following particular problems with the rule of law in Poland that fall under the scope of Article 7 TEU: the law amending the law on the Ordinary Courts Organization ('law on Ordinary Courts Organization'), published in the Polish Official Journal on July 28, 2017 and in force since August 12, 2017; the law amending the law on the National Council for the Judiciary and certain other laws ('law on the National Council for the Judiciary'); approved by the Senate on December 15, 2017; and the law amending the law on the National School of Judiciary and Public Prosecution, the law on Ordinary Courts Organization and certain other laws ('law on the National School of Judiciary'); published in the Polish Official Journal on June 13, 2017 and in force since June $20,2017$.

22 European Parliament, "Report on a Proposal Calling on the Council to Determine, Pursuant to Article 7(1) of the Treaty on European Union, the Existence of a Clear Risk of a Serious Breach by Hungary of the Values on Which the Union is Founded," (2017/2131 (NL)) Committee on Civil Liberties, Justice and Home Affairs (July 4, 2018), 5. 
In September 2018, the European Parliament asked the EU Member States to determine according to Article 7(1) TEU if Hungary is at risk of breaching EU's fundamental values, enshrined in Article 2 TEU. The request was overwhelming passed in the EU Parliament with 448 votes supporting the proposal against 197 votes against with 48 abstentions. The Report of the EU Parliament focused on twelve areas of concern with special focus on the independence of the judiciary and the rights of judges, the right to equal treatment, the functioning of the constitutional and electoral system in Hungary, among others such as corruption and conflict of interest, privacy and data protection, freedom of religion, freedom of association, the rights of persons belonging to minorities, and economic and social rights.

An emphasis of the EP proposal for a Council decision under the Article 7(1) TEU mechanism was the corruption and conflicts of interest in Hungary. The EP proposal specifically outlined that Hungary benefits from EU funding which amounts to approximately $4.4 \%$ of its GDP and more than half of its public investments. One problematic aspect is that Hungary has the highest number of recommendations issued by OLAF for the use of Structural Funds and CAP for the 2013-2017 period along with a fairly high number of contracts awarded in one-bidder proceedings at a rate of approximately $36 \% .{ }^{23}$ Serious irregularities and conflicts of interest were found by OLAF in several investigations for transport projects amounting to 1.7 billion EUR as well as granting contracts to companies, controlled by the PM's son-in-law. Other examples include misuse and abuse of Research and Development projects funds in cross-border investigations in Latvia, Hungary, and Serbia. Moreover, government efficiency has decreased in Hungary and the EU Anti-corruption Report of 2014 concluded that the perception of corruption is widespread in Hungary. As regards the conflicts of interest, GRECO has regularly reminded Hungary to improve the robustness of the asset declaration procedures. ${ }^{24}$

\section{Serious and Persistent Breach Determination and \\ Sanctioning Mechanism under Article 7(2-3) TEU}

The determination of the existence of a serious and persistent breach under Article 7(2) TEU could be initiated by $1 / 3$ of the Member States or the Commission with the consent of the European Parliament. The number of the actors who can trigger the procedure is restricted in comparison to the Article 7(1) TEU procedure in order to reflect the primarily political function of this stage of the mechanism. The threshold of determining the existence of a serious and persistent breach is unanimity at the Council, excluding the participation in the voting of the concerned Member State(s). In such manner, the effectiveness of the procedure is heavily restricted. The standard of assessment demands determination of a serious and persistent breach which would indicate a systemic nature of the breach of the Union value(s). In that regard, the

23 European Parliament, "Hungary Proposal under Article 7(1) TEU," 11.

24 European Parliament, "Hungary Proposal under Article 7(1) TEU," 11. 
Member State is to be proven incapable of resolving the problem of breaching the fundamental value on its own. ${ }^{25}$ In essence, there must exist "constitutional capture of the Member State institutions resulting in the paralysis of the liberal democracy and its institutions, thus making auto-corrections impossible." ${ }^{26}$ The mechanism under Article 7(2) TEU allows for determination of a serious and persistent breach which is a precursor to a sanctioning mechanism under Article 7(3) TEU if no remedy is achieved.

If Article 7(2) TEU finding of a serious and persistent breach is successful, the Council has the discretion to suspend certain rights of the concerned Member State(s), including voting rights of the Member State in the Council. The sanction is taken with qualified majority and requires a prior unanimous finding under Article 7(2) TEU.27 The sanction may affect certain rights from the application of the Treaties, including economic or non-economic ones, including Cohesion funds or other budget-related rights. Such a sanctioning mechanism of voting rights or certain rights and privileges of the breaching Member State under Article 7(2) TEU falls squarely under the recognized sanctions in public international law for international organizations as the "purpose is to exert sufficient pressure to induce addressees not to violate the rules in the future (the preventive function), or to stop current violations (the repressive function)." 28 The sanctions are lifted or altered by a Qualified majority (QMV) excluding the affected Member State under Article 7(4) TEU. No matter the severity of the breach, the mechanism does not authorize the expulsion of the Member States from the EU.

As Article 7(1) TEU proceedings were activated in the cases of Hungary and Poland for clear risks for serious breaches of the fundamental values of the EU, the reasons behind the warning part of the mechanism have been justified. The history of the Article 7 TEU mechanism proves its necessity in the toolbox of how EU institutions can respond to the undermining process of the EU fundamental values in some Central and Eastern European Member States along with other mechanisms, such as recent and ongoing infringement proceedings against the restructuring of the judiciary in Poland and Hungary. However, the Article 7 TEU mechanism is still heavily politicized, which is reflected in the political roadblocks and supermajority or unanimity voting requirement at the Council at the respective stages of the mechanism. This puts into question the effectiveness of the mechanism as a channel of enforcement of EU law and fundamental values. Additionally, the role of the Court of Justice of the EU is also restricted under Article 7 TEU. There is no express exclusion of Article 7 TEU from the Court of Justice of the European Union (CJEU)'s jurisdiction, although the Court would have jurisdiction over procedural issues such as the voting arrangement

What Has Been Done, What Can Be Done," Common Market Law Review 51, no. 1 (2014), 59.

Kochenov, "Busting the Myths," 10.

The QMV is reinforced under Articles 238(3)(b) and 354, thus requiring $72 \%$ of the participating Council Members comprising $65 \%$ of the Union population, excluding the concerned Member State(s). 
per Article 19 TEU and Article 269 of the Treaty of the Functioning of the European Union(TFEU). ${ }^{29}$ This affirms the notion that Article 7 TEU is primarily political in nature, more politicized in terms of the Institutional arrangement and slow progress, if any, in the dialogue between the involved institutions and the affected Member States, and less legal in its procedure but nonetheless fundamental in its function and purpose as a response to the rule of law regression and potential or actual breaches of core EU values. Due to the high risk of politicization roadblocks that may appear during the Article 7 proceedings at Council level and the minimized ability for legal enforcement, it is necessary to analyze various alternatives in the toolbox of the EU institutions such as the recently created EPPO.

\section{The European Public Prosecutor's Office (EPPO)}

The European Public Prosecutor's Office was established in October 2017 under Article 86(1) of the TFEU in the framework of the enhanced cooperation procedure. ${ }^{30}$ The significance of the establishment of the EPPO is reflected in the structure, function and competence of the EPPO in terms of its anti-fraud and anti-corruption direction and indirect influence on the rule of law in the participating Member States. As of the current moment, all EU member states with the exception of Denmark, Ireland, the UK, Sweden, Malta, Poland and Hungary participate in the EPPO framework. It is the first EU body that will have the powers to adopt decisions against individuals within the field of criminal law. ${ }^{31}$

The main rationale for the establishment of the EPPO has been linked to the efforts of the EU to secure a stronger and more efficient protection of its financial interests as well the overall push in the last 20 years in the area of EU criminal law that has facilitated the opportunity and legal basis to launch the EPPO. The EPPO is the logical continuation of the efforts at EU level to further cooperation in the area of criminal law as "Eurojust and Europol are...supporting bodies, which aim to facilitate the activities of national authorities coping with transnational criminality," while the EPPO will have the competence to investigate and prosecute individuals suspected of having committed the so-called "PIF" offences. ${ }^{32}$ Additionally, the EU has been recently active in responding to financial crimes of the EU budgets by legislating the Market Abuse Directive and the Regulation to counter white-collar crimes as part of the provisions under Article 114 TFEU. 33

29 Kochenov, "Busting the Myths," 6-7.

30 Council Regulation (EU) 2017/1939, OJ L283 (October 12, 2017).

$31 \quad$ See Fabio Giuffrida, "The European Public Prosecutor's Office: King without Kingdom?”

CEPS Research Report No 2017/O3 (Feb 2017): 1.

32 Giuffrida, "King without Kingdom," 5.

33 See Directive on criminal sanctions for insider dealing and market manipulation

(Directive 2014/57/EU, L173/179) and Regulation on Market Abuse (Regulation (EU)

No 596/2014). 


\section{Material Competence of the EPPO}

Preamble (11) of the EPPO Council Regulation stipulates that "the material scope of competence of the EPPO is limited to criminal offences affecting the financial interests of the Union," ${ }^{34}$ and the EPPO's task would be to "investigate, prosecute and bring to judgment the perpetrators of offences against the Union's financial interests" in pursuance of Directive 2017/1371. Article 3(2) of Directive 2017/1371 defines criminal offences of fraud affecting the EU's financial interests as well as revenue arising from VAT own resources in cross-border fraudulent schemes, involving a total damage of at least 10 million euro. ${ }^{35}$ Additionally, Article 4 of the Directive 2017/1371 includes other criminal offences affecting the EU's financial interests. It obliges Member States to criminalize money laundering and property derived from that criminal offence under Article 1(3) of the Directive 2015/849.

The most relevant provision for this paper is contained in Article 4(2) of Directive 2017/1371 which states that "Member States shall take the necessary measures to ensure that passive and active corruption, when committed intentionally, constitute criminal offences" in their respective domestic legal orders. The Directive defines "passive corruption" as "the action of a public official who, directly or through an intermediary, requests or receives advantages of any kind, for himself or for a third party, or accepts a promise of such an advantage, to act or to refrain from acting in accordance with his duty or in the exercise of his functions in a way which damages or is likely to damage the Union's financial interests." ${ }^{36}$ Active corruption involves the act of an individual "who promises, offers or gives, directly or through an intermediary, an advantage of any kind to a public official for himself or for a third party for him to act or to refrain from acting in accordance with his duty or in the exercise of his functions in a way which damages or is likely to damage the Union's financial interests." ${ }^{37}$ A public official means "a Union official or a national official, including any national official of another Member State and any national official of a third country" 38 The trigger of the applicability of the corruption offences is based on the damage or likely damage to the EU's financial interests. In this manner, the threshold is set fairly high in terms of the 'damage' requirement, while the EU's financial interest part allows for the scope of the criminal offence to include the fraud activities per Article 3 of Directive 2017/1371.

The EPPO Regulation requires that the PIF criminal offences are to be implemented by national law, "irrespective of whether the same criminal conduct could be classified as

See also, Article 1 Council Regulation 2017/1939, defining 'financial interests of the Union' as "all revenues, expenditures and assets covered by, acquired through, or due to the Union budget and the budgets of the institutions, bodies, offices and agencies established under the Treaties and budgets managed and monitored by them."

35 See Article 22(1) of Regulation 2017/1939.

36 Article 4(2)(a) of EU Directive 2017/1371, L198/29 (July 5, 2017).

37 Article 4(2)(b) of EU Directive 2017/1371.

$3^{8}$ Article 4(4)(a) of EU Directive 2017/1371. 
another type of offence under national law." 39 This means that the material competence of the EPPO is to be regulated by national law as the aim of the PIF Directive is to provide a minimalistic degree of harmonized domestic legislation in order to enable an effective response to the criminal offences. ${ }^{40}$ Nonetheless, the material scope of the EPPO competence is extended per Article 22(3) of the EPPO Regulation because the EPPO has competence for "any other criminal offence" that is "inextricably linked" to the PIF criminal conduct under Article 22(1). This is because the efficient investigation of the PIF offences along with the ne bis in idem principle may require "an extension of the investigation to other offences under national law" which are inextricably linked to the PIF offence(s). ${ }^{41}$ The qualification "inextricably linked" is assessed in light of the relevant case-law with an emphasis on the relevant criterion of the material facts or substantially same facts "understood in the sense of the existence of a set of concrete circumstances which are inextricably linked together in time and space" as regards the ne bis in idem principle.

Another guiding criterion in analyzing the inextricable nature of the offence is the preponderance of the effect of the offence on the EU's financial interests which may include an assessment of the maximum sanction that the offence carries as the PIF offence must carry a higher maximum sanction than the ancillary offence ${ }^{42}$ as well as the ancillary nature of the offence which is instrumental to the PIF offence where the main purpose of the ancillary crime is to create the conditions to commit the PIF offence. ${ }^{43}$ In this manner, the ancillary offence can encompass acts of corruption.

If a disagreement exists between the EPPO and the national prosecution authorities as regards the criminal conduct under Article $22(2-3)$, it is the prerogative of the national authorities to decide on the attribution of competences of the investigation of the case. ${ }^{44}$ In this manner, the EPPO is restricted to decide on its own jurisdiction as "placing the Kompetenz-Kompetenz in the hands of the national bodies shows the inherent peculiarity of the Office," namely that national laws constrain the procedures and overall structure of the EPPO. ${ }^{45}$

\section{Structure of the EPPO}

The structure of the EPPO is characterized as "an indivisible Union body operating as one single Office" with a decentralized structure and it shall be organized at central

Article 22(1) of Regulation 2017/1939.

Giuffrida, "King without Kingdom," 9.

Preamble 54 of Regulation 2017/1939. For the ne bis in idem principle, see Stoyan Panov,

"The Obligation Aut Dedere Aut Judicare ('Extradite or Prosecute') in International Law."

PhD diss, University of Birmingham, 2016, 16o-64.

See Article 25(3) of Regulation 2017/1939.

Preamble $55^{-56}$ of Regulation 2017/1939.

Article 25(6) of Regulation 2017/1939.

Giuffrida, "King without Kingdom," 12. 
and decentralized levels. ${ }^{46}$ The central level is structured around a Central Office, composed of the College, the Permanent Chambers, the European Chief Prosecutor (ECP), the European Deputy Prosecutors, the Administrative Director, and the European Prosecutors (EP). ${ }^{47}$ The European Chief Prosecutor is the head of the EPPO, with responsibilities to organize the work of the EPPO, to guide its activities and to take decision in accordance with the Regulation and the relevant rules of procedure. ${ }^{48}$ According to Article 9(1-2) of the EPPO Regulation, the College, consisting of the ECP and one EP from each participating Member State, is tasked with the general oversight of the EPPO activities and with taking decision of strategic matter along with general issues arising from individual cases with focus on ensuring coherence, efficiency and consistency in the EPPO prosecution policy explicitly excluding taking operational decisions in individual cases.

The Permanent Chambers, which number is to be determined, is chaired by the ECP or one of the European Deputy Prosecutors in the Chair capacity along with two additional members. ${ }^{49}$ The task of the Permanent Chambers is three-fold: to "monitor and direct investigations and prosecutions conducted by the European Delegated Prosecutors," to "ensure coordination of the investigations and prosecutions in crossborder cases" and to implement "decisions taken by the College." 50 In this manner, the Permanent Chambers are envisaged to be the most important operative organ of the EPPO. The European Prosecutor responsible for the supervision of the investigation or prosecution also participates in the deliberation of the Permanent Chambers. ${ }^{51}$ The European Prosecutor supervises the investigations and prosecutions of the European Delegated Prosecutor (EDP) handing the case in the relevant Member State(s) of origin. ${ }^{52}$ The European Prosecutor acts as a liaison between the Permanent Chambers and the European Delegated Prosecutors. ${ }^{53}$

The Decentralized level is structured around at least two European Delegated Prosecutors in each Member State. ${ }^{54}$ The EDPs act on behalf of the EPPO in their respective Member States and have the same powers as national prosecutors as regards investigations, prosecutions and bringing cases to judgment along with their specific powers in pursuance of the EPPO Regulation. 55 The EDPs are labeled to have a "dual hat" function as they may exercise functions of national prosecutors as long as the two

\footnotetext{
46 Article 8(2-3) of Regulation 2017/1939.

47 Article 8(3) of Regulation 2017/1939.

48 Article 11(1) of Regulation 2017/1939.

49 Article 10(1) of Regulation 2017/1939.

$5^{\circ} \quad$ Article 10(2) of Regulation 2017/1939.

$51 \quad$ Article 10(9) of Regulation 2017/1939.

$5^{2}$ Article 12(1) of Regulation 2017/1939.

53 Article 12(5) of Regulation 2017/1939.

54 Article 13(2) of Regulation 2017/1939.

55 Article 13(1) of Regulation 2017/1939.
} 
functions do not conflict with their obligations under the EPPO Regulation. ${ }^{56}$ The EDPs are responsible for the investigations and prosecutions that they have initiated or have been allocated to them or they have taken under the right of evocation. ${ }^{57}$ The European moment is that national judicial and law enforcement authorities shall without undue delay notify the EPPO about investigations of offenses within the competence of the EPPO in order for the EPPO to determine whether to exercise the evocation privilege. ${ }^{58}$ In accordance with the applicable national law, the EDP, based on "reasonable grounds to believe that an offence within the competence of the EPPO is being or has been committed," shall initiate the investigation and, if no such investigation has been launched by the EDP, the Permanent Chamber shall instruct the EDP to initiate the investigation. ${ }^{59}$ In terms of the right of evocation, the EDP shall take its decision within 5 days after learning about the case from the national authorities according to Article 27(1) of the EPPO Regulation.

According to Article 30 of the EPPO Regulation, the EDPs are entitled to request investigative measures such as searches of premises, freezing orders of assets and proceeds of crime, interception of electronic communication among others in the framework of the applicable domestic law. ${ }^{60}$ The EDPs can order the arrest or pretrial detention of the suspect or accused person in accordance with the national law applicable in similar domestic cases along with issuing a European Arrest Warrant for the surrender of the individual. ${ }^{61}$ Moreover, the EDP has the competence to complete investigations and submit a report to the supervising European Prosecutor with a summary of "prosecute before a national court or to consider a referral of the case, dismissal or simplified prosecution procedure." ${ }^{2}$ In this manner, the EDP is the kingpin of the investigation stage.

In the next stage of the process, the European Prosecutor, based on its own assessment, may forward the documentation to the Permanent Chambers. ${ }^{63}$ The Permanent Chamber decides whether the case is to be brought to judgment or referred

56 Katalin Ligeti and Michele Simonato, “The European Public Prosecutor's Office: Towards a Truly Prosecution Service?" The New Journal of European Criminal Law 4, no. 1-2 (2013): 15 . See also, Article 13(3) of Regulation 2017/1939.

57 Article 13(1) of Regulation 2017/1939.

$5^{8}$ Article 24(2) of Regulation 2017/1939.

59 Article 26(1) and (3) of Regulation 2017/1939.

6o The standard of review is established in Article 30(5) of Regulation 2017/1939: "The European Delegated Prosecutors may only order the measures referred to in paragraphs 1 and 4 where there are reasonable grounds to believe that the specific measure in question might provide information or evidence useful to the investigation, and where there is no less intrusive measure available which could achieve the same objective. The procedures and the modalities for taking the measures shall be governed by the applicable national law."

$61 \quad$ Article 33(1-2) of Regulation 2017/1939.

62 Article 35(1) of Regulation 2017/1939.

63 Article 35(1) of Regulation 2017/1939. 
to the relevant national prosecutorial authorities, ${ }^{64}$ whether to be dismissed, ${ }^{65}$ or whether to be concluded by utilizing simplified prosecution procedures under national law. ${ }^{66}$ If the EDPs submit the case to judgment, the Permanent Chamber decides on this proposal within 21 days but the Chamber cannot decide to dismiss the case. ${ }^{67}$ The Permanent Chamber plays an essential role in the prosecutorial stage. Hence, scholars label this as the "European moment" between the investigation and trial stages, which are regulated by national law. 68

The Permanent Chamber plays an essential role in the determination to prosecute a case where more than one Member State has jurisdiction over the case. In such circumstances the decision is taken in pursuance to Article 26(4-5) of the EPPO Regulation. The Permanent Chamber is responsible for dismissal of the cases where prosecution has become impossible, on the grounds of the death of the suspect or accused person, the insanity plea, an amnesty granted to the suspect or accused person, immunity, an expiration of the national statute of limitation to prosecute, the $n e$ bis in idem principle, and a lack of relevant evidence. ${ }^{69}$ As domestic rules of immunities as well as statute of limitation vary among the Member States, this may lead to fragmentation in light of the lack of a significant substantive criminal law framework at European level. ${ }^{70}$

The structure of the EPPO is "multi-level, complex and at first sight rather bureaucratic system...with clear and strong intergovernmental elements." ${ }^{71}$ The crucial organ of the EPPO is designed to be the Permanent Chambers, a collegiate body that involves the representatives from members where the investigations and prosecutions occur. This narrow opportunity for supranational decision-making by the Permanent Chamber begs the question if the Permanent Chamber would dare take decisions that may contradict the EDP's guidance. The most controversial aspect would be situations in which the Permanent Chamber may decide against the recommendation of the EDP as the latter come from the jurisdictions where the investigations take place. Hence, it is not surprising that "splitting the level of regulation of the activities of the EPPO (mainly national law) and the level on which decisions are adopted (Permanent Chamber) can in fact lead to a catch-22 situation." ${ }^{2}$ The possible chasm between the Chambers and

64 Article 38 of Regulation 2017/1939.

65 Article 39 of Regulation 2017/1939.

66 Article 4O(1) of Regulation 2017/1939.

67 Article 36(1) of Regulation 2017/1939. If the Permanent Chamber does take a decision with the 21-day period, the EDP's decision is accepted (see Article 36(2) of Regulation 2017/1939).

68 Giuffrida, "King without Kingdom," 28.

69 Article 39(1) of Regulation 2017/1939.

70 See Case C-105/14, Taricco and others case (September 8, 2015). See also, Giuffrida, "King without Kingdom," 27.

71 Valsamis Mitsilegas and Fabio Giuffrida, "Raising the Bar? Thoughts on the Establishment of the European Public Prosecutor's Office," CEPS Policy Insight No 2017-39 (November 30, 2017): 7 .

Mitsilegas, and Giuffrida, "Raising the Bar?" 8. 
EDPs may cause significant disruption of the functionality of the EPPO. Moreover, there might be situations in which the EDPs might not be able to exercise their functions due to various types of interference by national authorities. The protection that the EPPO offers is that the national authorities shall "refrain from any action or policy that may adversely affect [EDP's] career or status in the national prosecutorial system." 73

Another problem may occur in the coordination stage and roles of the Centralized and Decentralized levels. It is not clear what settlement mechanism can be applied if the EDPs receive conflicting guidance from the supervising European Prosecutor and the Permanent Chamber. A mere change of the EDP would not suffice in resolving the substantive conflict between the European Prosecutor, who may be more knowledgeable in the particular jurisdiction where the investigation takes place, and the Permanent Chamber. ${ }^{74}$ Moreover, the supervising European Prosecutor and the members of the relevant Permanent Chamber may come from different jurisdictions in comparison to the locus of the case, thus raising issues about the over-reliance on the expertise of the responsible EDP.

The Permanent Chamber has the competence in cases concerning the jurisdiction of more than one Member State, after consulting with the European Prosecutors and/ or the EDP to reallocate the case to an EDP in another MS or to merge or split cases by appointing a handling EDP if such decisions are in the general interest of justice and taking into consideration the priority criteria such the place of the habitual residence of the suspect, the nationality of the suspect or accused person, or the place where the main financial damage has occurred. ${ }^{75}$ Moreover, the Permanent Chamber, upon proposal by the supervising European Prosecutor, may decide to reallocate the case to another EDP in the same jurisdiction when the handling EDP "cannot perform the investigation or prosecution; or fails to follow the instruction of the competent Permanent Chamber or the European Prosecutor." ${ }^{66}$ The described mechanism of the reallocation is not subject to judicial review at the EU level. ${ }^{77}$ One possible solution to the lack of judicial review for the forum choice could be the delegation of the task to national courts which may apply judicial scrutiny as long as "an appropriate 'yardstick"” is provided from the EU framework since, without an adequate EU-based standard, the "national court will hardly be in the position to review a multilateral choice of forum." 78 In the absence of a clear yardstick, diverging decisions by national courts may

73 Article 96(6) of Regulation 2017/1939.

74 Giuffrida, "King without Kingdom," 15.

75 Article 26(5) of Regulation 2017/1939.

76 Article 28(3) of Regulation 2017/1939.

77 Giuffrida, "King without Kingdom," 18.

78 Martin Wasmeier, "The Choice of Forum by the European Public Prosecutor," in The European

Public Prosecutor's Office. An Extended Arm or a Two-Headed Dragon?, eds. Leendert

Erkelens, Arjen Meij and Marta Pawlik (Berlin-Heidelberg: T. M. C. Asser Press \& Springer-

Verlag, 2015), 154 . 
result in conflicting and fragmented jurisprudence, thus undermining the principles of consistent interpretation. ${ }^{79}$

Cross-border investigations may be necessary in some cases. In such circumstances, the handling EDP decides on the necessary measures to be applied in another jurisdiction and assigns such to the assisting EDP. ${ }^{80}$ A problem may arise when a judicial authorization is required under the law of the jurisdiction of the assisting EDP. In such cases, the assisting EDP is required to obtain the requisite authorization in accordance with the law of that Member State. ${ }^{81}$ In case of authorization refusal, the handling EDP would withdraw the assignment. This begs the question whether the requested authorization by the assisting EDP is to be evaluated by the judicial authority in the assisting Member State in a matter which may "deny the authorisation of the measure on broader grounds than those foreseen in the EIO Directive." ${ }^{2}$ To some degree, Article 31(6) of the EPPO Regulation responds to the conundrum as it stipulates that the if the assigned measure does not exist in a purely domestic situation, "but would be available in a cross-border situation covered by legal instruments on mutual recognition or cross-border cooperation, the European Delegated Prosecutors concerned may, in agreement with the supervising European Prosecutors concerned, have recourse to such instruments." In this manner, the single legal area envisaged by the EPPO Regulation is qualified by the applicability of the principle of the mutual recognition.

The complex structure of the EPPO and relation with national judicial and prosecutorial authorities may be teleologically explained through the subsidiarity principle and the established principle that Member States are obliged to protect the interests of the EU through consistent interpretation of EU law, especially when it comes down to financial crimes against the EU budget as "the Member States must ensure that infringements of EU law are penalised under conditions, both procedural and substantive, which are analogous to those applicable to infringements of national law of a similar nature and importance and which, in any event, make the penalty effective, proportionate and dissuasive." 83

\section{Judicial Review of the EPPO}

In the EU supranational legal order, legitimizing how power is regulated and why law is equitable becomes highly relevant. Legitimacy could be understood to be substantive as to how fair and appropriate rules or institutions are, or procedural as to how the process by which rules are created is equitable, transparent and accessible. ${ }^{84}$ The role

79 See Rosas and Armati, 72-73.

8o Article 31(1) of Regulation 2017/1939.

81 Article 31(3) of Regulation 2017/1939.

82 Anne Weyembergh and Chloe Brière, "Towards a European Public Prosecutor's Office (EPPO),"

European Parliament, Civil Liberties, Justice and Home Affairs (2016):32.

83 Case C-68/88 Commission v Greece [1989] ECR 1-2965, para 24.

84 Bianchi, International Law Theories, 53. 
of judicial review is particularly significant in such a legal order as it "aims to tame the beast of politics: it sends the message that no matter what politics may decide, it cannot overstep the bounds of law." 85 The administration of judicial review is crucial as it ensures a basic form of accountability of public power, which may be particularly prone to corruption, through the principle of transparency in order to protect "individuals against unauthorized or arbitrary exercises of official power, and also promot(ing) administrative responsiveness to broader public interest." 86 The law tames the power and brings legitimacy to "check and steer the exercise of government power." ${ }^{87}$ In this manner, the crux of the analysis is to what degree the judicial review on national and EU levels is appropriate, legitimacy enhancing of the acts of the EPPO, and striking the balance of subsidiarity and consistent interpretation of EU law.

The law is determinable by public recognition in the sense that the public aspect requires clearly identifiable principles of legality, accountability, transparency, proportionality and judicial review. ${ }^{88}$ The common themes of the rule of law paradigm aim "to restrain power and hold decision-makers accountable, the ideal of a society based on shared values, the systematization of the law, and the foundational role of human rights." ${ }^{99}$ Such principles are particularly relevant for supranational institutions, which are criticized for lacking democratic legitimacy and are necessary in order to check and balance the institutions through judicial review. ${ }^{90}$ In this manner, the issues of legitimacy, public accountability and judicial review would be particularly relevant for the newly established EPPO as its function may directly affect fundamental rights of individuals while there is an opportunity that it may serve as a model for procedural and substantive human rights guarantees in its investigations and prosecutions.

The principle of judicial review is fundamental for subjecting the authority primarily responsible for investigative and prosecutorial acts that affect human rights of individuals to an impartial and independent judicial oversight. As the prosecutorial stages may inflict certain restrictions on the enjoyment of fundamental rights and freedoms, the criminal procedure must be clearly defined, laid down and publicly accessible in law, including the protective mechanisms for individuals, involved in or affected by such proceedings. As the restraint on fundamental rights is to be triggered and applied by the public authorities at domestic and/or supranational levels, independent courts should be tasked to review and control the acts and decision of the investigative

85 Jan Klabbers, "Setting the Scene" in The Constitutionalization of International Law, eds. Jan Klabbers, Anne Peters, and Geir Ulfstein (Oxford: OUP, 2009), 27.

86 Benedict Kingsbury, Nico Krisch, Richard Stewart and Jonathan Weiner, "Global Governance as Administration- National and Transnational Approaches to Global Administrative Law," Law and Contemporary Problems 68, (Summer 2005) 1, 4.

87 Kingsbury et al., "Global Governance," 4.

88 See Bianchi, International Law Theories, 64.

89 Bianchi, International Law Theories, 67.

90 See Eyal Benvinisti, The Law of Global Governance (The Hague: The Hague Academy of International Law 2014), 286-87. 
and prosecutorial body. Moreover, in modern prosecutorial frameworks, the role of the prosecutor encompasses such activities as ascertaining the legal requirements for investigation and prosecution, the collection of inculpatory or exculpatory evidence, in a framework seemingly merging the investigative and prosecutorial realms. ${ }^{91}$ Judicial review is particularly relevant for prosecutorial authorities as the impartiality of the office of the prosecutor may sometimes be clouded in the process of assessment of the legal requirements and applicability of impartiality as it ultimately aims at securing successfully the investigative and prosecutorial function. ${ }^{92}$ Judicial review is pertinent when complex supranational entities such as the EPPO are concerned.

Article 42 of the EPPO Regulation lays down the judicial review framework. The procedural acts of the EPPO intended to produce legal effects vis-a-vis third parties are subject to review performed by "the competent national courts in accordance with the requirements and procedures laid down by national law." In this manner, the national courts can apply not only EU law but also have recourse to obligations of all EU Member States under the ECHR. Such a review would encompass the procedural protections of the accused persons under the framework of Article 6 ECHR as well as it may include the procedural aspects of the relevant rights guaranteed under Articles 5, 8 and Article 1 Protocol 1 of the ECHR.

\section{Judicial Review at the EU Level}

Judicial review is not exclusively assigned to national courts. Article 42(2) of the EPPO Regulation stipulates that pursuance to Article 267 TFEU, the CJEU has jurisdiction to give preliminary rulings in three circumstances:

1) on the validity of procedural acts of the EPPO, as long as the validity issue is raised before any national court directly on the basis of EU law;

2) on the interpretation or the validity of provisions of EU law and the EPPO Regulation; and

3) on the interpretation of the material competence of the EPPO as established in Articles 22 and 25 of the EPPO Regulation in relation to any conflict of competence between the EPPO and the national authorities.

As the EPPO Regulation is an act of the Council, the competence of the CJEU to interpret the validity of the EPPO act(s) is derived from Article 267(1)(b) TFEU. In this manner, the CJEU has competence on the interpretation and validity of the acts of the EPPO when the national courts have reasonable belief that the particular act violates EU law, including the Charter of Fundamental Rights (CFR) protections, the Treaties or the EPPO Regulation itself.93

91 Denis Salas, “The Role of the Judge”, in European Criminal Procedures, eds. Mirelles DelmasMarty and J. R. Spencer (Cambridge: Cambridge University Press, 2002), 497-98.

Ante Novokmet, “The European Public Prosecutor's Office and the Judicial Review of Criminal Prosecution," New Journal of European Criminal Law 8, no. 3 (2017): 379.

93 Giuffrida, "King without Kingdom," 33. See also, Albertina Albors-Llorens, "Remedies against the EU Institutions After Lisbon: An Era of Opportunity?" Cambridge Law Journal 71, no. 3 
However, there is criticism that could be raised as to the effectiveness of the remedy under Article 267 TFEU. In essence, national judges cannot invalidate EU measures but only refer the question of the validity to the CJEU, especially in cases of serious doubts about the validity of the measure, while the private litigants "cannot initiate proceedings concerning the invalidity of EU law via Article 267 TFEU as a matter of legal right." 94 If the plaintiff fails to bring a challenge of validity under Article 263(4) TFEU within a two-month period and the plaintiff had legal standing to do so, the plaintiff would not have recourse under Article 267 TFEU to challenge the validity. ${ }^{95}$

The EPPO Regulation offers another avenue for supranational judicial review. Article $42(3)$ of the EPPO Regulation provides for the CJEU to rule on the legality of the decisions of the EPPO in cases where the EPPO decides to dismiss a case, "in so far as they are contested directly on the basis of Union law" under the action for annulment in Article 263(4) TFEU. In this manner "any natural or legal person may... institute proceedings against an act addressed to that person or which is of direct and individual concern to them, and against a regulatory act which is of direct concern to them and does not entail implementing measures." 96 The mechanism allows for judicial review over Article 39 of the EPPO Regulation which deals with dismissal of the cases. The CJEU may be involved in situations where the dismissal is pursuant to a basis which is not exclusively listed in the grounds for dismissal under Article 39 of the EPPO Regulation or where the decision for dismissal has breached the procedure. ${ }^{97}$ As the dismissal procedure is ultimately in the hands of the Permanent Chambers, it is not surprising that the decisions of the Permanent Chambers would be subject to judicial review by the CJEU. Authors suggest that the dismissal is particularly important for the overall function and purpose of the EPPO as the review mechanism aims at ensuring that cases would not be arbitrarily dismissed.98

The action for annulment under Article 263(4) TFEU may provide the answer to a strict judicial review of the acts of the EPPO on EU level. The CJEU has elaborated that the standing criteria for natural and legal persons include that the binding legal effects of the contested act are capable of affecting the interests of the applicant by bringing a distinct legal change the legal position of the applicant. ${ }^{99}$ In this manner, the rights of the accused person or suspect could be reviewed under Article 263(4) TFEU. The issue becomes pertinent as regards the occurrence of the distinct legal change. In the Tillack case, the CFI interpreted that sharing of information between domestic judicial authorities and an EU body such as OLAF which may result in the commencement of an investigation on a domestic level does not necessarily in itself bring a distinct legal

(2012): 510 .

94 Steve Peers and Mario Costa, "Court of Justice of the European Union Judicial Review of EU

Acts after the Treaty of Lisbon" European Constitutional Law Review 8, no. 2 (2012): 98.

96 Article 263(4) TFEU.

97 Giuffrida, "King without Kingdom," 33.

98 Giuffrida, "King without Kingdom," 33-34. 
change in the legal position of the suspect or investigated individual. ${ }^{100}$ The decision was based on the exclusive competence of the domestic prosecutorial authorities to follow up on the legal proceedings which may be influenced by the information or evidence provided by the EU body. ${ }^{101}$ The situation in the EPPO as regards investigative measures is slightly different in terms of decision-making in comparison to exclusive domestic competence of the domestic investigative or prosecutorial bodies. Moreover, the Tillack case reached the ECtHR as there was an issue with a search of the suspect's property without reasonable ground to do so. The ECtHR took a different approach from the CJEU by concluding that the measures applied by Belgium were disproportionate as regards Tillack's freedom of expression under Article 1o ECHR. Hence, the Court in Strasbourg was willing to extend another protective mechanism, based on the interpretation that the exchange of information between the domestic authorities and OLAF did lead to an interference with his rights under the ECHR. ${ }^{102}$

It could be envisaged that the Article 263(4) TFEU challenge would be primarily used for review against acts addressed to the person concerned, although the challenges allow for legal standing against legislative and/or regulatory acts of general application subject to the direct and individual concern threshold as well as regulatory acts subject to direct concern where no implementing measure is entailed. ${ }^{103}$ However, it begs the question why other acts of the Permanent Chambers were not included under this limb of judicial review. This may go against the grain of Article 47 of the CFR as well as Article 19(1) TEU as "Member States shall provide remedies sufficient to ensure effective legal protection" in the fields of EU law, meaning that the judicial system of the EU includes the CJEU along with national courts in order to function as "complete system of legal remedies and procedures designed to ensure review of the legality of acts of the institutions." 104 Moreover, the Article 263(4) TFEU challenge is known as "creating a formidable barrier of standing for private parties." 105

The CJEU has jurisdiction to any disputes concerning compensation for damages caused by the EPPO under Article 268 TFEU. ${ }^{106}$ Under Article 340 TFEU, the EU bodies are liable for damages, based on a three-part test: 1) the illegal act by an EU body where the there is a sufficiently serious breach of EU law which intends to confer rights to individuals and the serious breach is caused by the EU body that "manifestly

100 Case T-193/o4 Hans-Martin Tillack v. Commission [2006] ECR II-3995, para 68.

102 Tillackv. Belgium no. 20477/O5 (ECtHR judgment 2007). See also, Novokmet, "The European Public Prosecutor's Office and the Judicial Review," 394.

103 Peers and Costa, "Court of Justice of the European Union Judicial Review," 85-86. See also, Case C-5o/ooP, Union de Pequenos Agricultores (UPA) v. Council [2002] E. C. R. I-6677. Opinion 1/2009 (March 8, 2011) para 66. For definition of regulatory acts, see Case C-583/11 P Inuit ECLI: EU: C:2013:625, para. 12. See also, Peers and Costa, "Court of Justice of the European Union Judicial Review," 95.

105 Albors-Llorens, "Remedies against the EU Institutions after Lisbon," 513.

106 Article 42(4) of Regulation 2017/1939. 
and gravely disregarded the limits of its discretion"; 2) actual damage caused to the concerned individual; and 3) a causal link or relation between the illegal act and the damage..$^{107}$

The judicial review of the EPPO is structured on a mix of national court competences and the CJEU's ability to review the EPPO's acts or omissions to act. The role of the CJEU seems rather limited as the major brunt of the judicial review is to be carried out on domestic level by domestic courts (one exception is that the CJEU has jurisdiction over the dismissal of the European Chief Prosecutor or European Prosecutors in accordance with Articles 14(5) and 16(5) of the EPPO Regulation).108 One criticism of such an approach is that national courts would adjudicate on acts by an EU body with the potential for decisions and acts of the EPPO to fall outside of the scope of the judicial review at EU level. ${ }^{109}$ Articles 263 and 265 TFEU exist in order to afford the highest possible level of protection as regards the review of the validity of acts or omissions by EU bodies and the restrictions in the EPPO Regulation seem at odds with the overall architecture of judicial review at EU level. ${ }^{110}$ Article 265 TFEU allows the privileged applicants such as Member States, the European Parliament, the Council, and the Commission among others as well as non-privileged applicants such as individuals when the body concerned should have addressed an act specifically to them to challenge the omission when there is a clear and well-defined duty to act."11 The restrictive scope may go against the tenet of Articles 47 and 49 of the CFR as well as the established jurisprudence which obligates the EU to uphold and protect fundamental rights, including the right to a fair trial via judicial review. Article $5^{1}$ of the CFR guarantees that the principle of judicial review is a fundamental human right from unlawful interference by EU's institutions and bodies.

One possible explanation that was offered for the unique structure of judicial review of the EPPO is that the judicial review must not contradict the principle of subsidiarity. The argument is based on the premise that national courts must have more active role in the review of EPPO acts as the dual hat function of the body may create more legal effects in the domestic legal orders. However, such an interpretation of the subsidiarity principle has been subject to disagreement as "the subsidiarity test...is whether the European Union level is the right level of legislative action with regard to the establishment of the EPPO to achieve the stated legislative objectives." ${ }^{112}$

107 See Case C-46 and 48/93 Brasserie du Pêcheur [1996] ECR I-1029, and Case C-352/98P Bergadem [2000] ECR I-5291.

108 Article 42(7) of Regulation 2017/1939.

109 Mitsilegas and Giuffrida, "Raising the Bar?" 13.

110 Weyembergh and Brière, "Towards a European Public Prosecutor's Office," 38.

111 Case 13/83 Parliament v. Council (Transport Policy), ECLI: EU: C:1985:220. See Albors-Llorens, "Remedies against the EU Institutions after Lisbon," 530-31. 


\section{Human Rights, Judicial Review and Acts of the EPPO}

Another related argument tries to pin down a clear distinction between the different types of the EPPO acts. Although the rules of the Regulation have primacy over national law when the matter is governed by both, national law plays a supplementary part when the matter of investigations and prosecutions are not regulated by the EU law including the Regulation. ${ }^{113}$ For example, this reasoning differentiates that the national courts should deal primarily with the review of the EPPO acts in the investigative stage while the prosecutorial acts are subject to more scrutiny at EU level. Such a differentiation is somewhat formalistic, for all mentioned acts are adopted by the same EU body, which should normatively be subject to judicial review at EU level.14 There is hardly any disagreement that judicial review must cover the investigative and prosecutorial stages in the criminal proceedings. The decisions of the prosecutor that are linked to initiation, continuation, dismissal or bringing to court the criminal prosecution may involve coercive measures against the accused or suspected individuals. Hence, such measures may merit more scrutiny in comparison to investigative acts which may be of equal or lesser coercive nature as a search of property or questioning of witnesses. ${ }^{115}$

In the same vein of reasoning, an interpretation of the legal basis of the EPPO, namely Article 86 TFEU, may be relevant too. Article 86(2) TFEU states that the EPPO "exercises the functions of prosecutor in the competent courts of the Member States" which may be interpreted that judicial review is also possible for investigative or pretrial stages based on EU law. This is a pertinent issue as investigations may include various "informal" operations in order to gather enough evidence to assess whether a crime has been committed or not. In this manner, if criminal prosecution does not cover that period, the rights of the person under investigation are strictly speaking not affected yet. This is important for the moment of applicability of the defense safeguards and especially relevant for the moment in which the person becomes a suspect.

Nonetheless, an over-reliance on judicial review by the CJEU may create a pragmatic inconvenience for the parties to the relevant proceedings as such proceedings may be prolonged or possibly carry higher litigation costs at EU level.116 Additionally, it is noticeable that the possibility for judicial review of the initiation of an investigation is absent in the EPPO framework. One possible explanation is linked to an analogy from the ECHR jurisprudence that the initiation of an investigation in itself does not affect human rights at that moment. ${ }^{117}$ However, when it comes down to the initiation of the investigation, certain restrictions exist, primarily related to the existence and assessment of facts or information from an objective person perspective in order to determine whether the person might have committed the offence. The ECtHR

113 Article 5(3) of Regulation 2017/1939.

114 Mitsilegas and Giuffrida, "Raising the Bar?" 14.

115 Novokmet, “The European Public Prosecutor's Office and the Judicial Review," 377.

116 Giuffrida, "King without Kingdom," 34.

117 Novokmet, “The European Public Prosecutor's Office and the Judicial Review," 385. 
jurisprudence relies on an assessment of the criminal proceedings as a whole, including the pre-trial stage. ${ }^{118}$ Although it might be argued that the investigative stage does not necessarily have to result in the determination of a criminal charge, thus triggering the applicability of Article 6 ECHR, the steps taken by the judicial authorities at that stage might have a direct influence on the conduct and fairness of the subsequent proceedings. Hence, some procedural safeguards must be applicable during that stage such as impartiality of the investigative judge as the right to a fair trial in the broad sense requires so, as well as the rights guaranteed by Article 6(3)(c) ECHR. For example, certain provisional measures which affect the fundamental rights of the person subject to a criminal investigation requires that the investigative judge, like any other judge, be objectively and subjectively impartial. ${ }^{119}$ The validity of proceedings in the assessment during the pre-trial investigation is based on what acts the prosecutorial or investigative entities have taken, especially in cases of evaluating the legitimacy and proportionality of the start, duration and continuation of the investigation. ${ }^{120}$ In a nutshell, the ECtHR jurisprudence may be inclined to include cases where the protected rights can be breached if the person is investigated outside of the scope of the reasonable grounds test or if the investigation is prolonged unnecessarily long which results in obstruction of judicial proceedings. ${ }^{121}$

Is it the moment of initiating the first investigation act, the moment of arrest, or the first interrogation of the person as a suspect by the EDP which trigger the full scope protection under the right to a fair trial? ${ }^{122}$ The questions are pertinent as guidance may be found in the jurisprudence of the ECtHR, namely the applicability of the guarantees under the criminal limb of Article 6(1) ECHR, linked with the substantive evaluation of the "charge" which may include "official notification given to an individual by the competent authority of an allegation that he has committed a criminal offence or from some other act which carries the implication of such an allegation and which likewise substantially affects the situation of the suspect." ${ }^{123}$ In this line of reasoning, when the person is charged is crucial and "this may have occurred on a date prior to the case coming before the trial court such as the date of the arrest, the date when the person concerned was officially notified that he would be prosecuted, or the date when the

118 Dvorskiv. Croatia, App. No. 25703 (ECtHR Judgment of October 20, 2015), para 76.

119 Micallefv. Malta, App. no. 17056/o6, (GC ECtHR judgment of October 15, 2009), para. 86, and Vera Fernández-Huidobro v. Spain, App. no. 74181/o1 (ECtHR Judgment of January 6, 2010), paras. 108-14.

Pelissier and Sassi v. France, [2000] 30 EHRR 715, para. 73. See also, Corigliano v. Italy,

App. no. 8304/78 (ECtHR judgment of December 10, 1982), paras. 49-50.

Novokmet, "The European Public Prosecutor's Office and the Judicial Review," 386. See also, Celina Nowak, "Judicial Control of the Prosecutor's Activities in the Light of the ECHR," Eucrim 2, (2014): 61. 
preliminary investigations were opened." 124 In this manner, the EPPO is provided with a choice as to the time when the person becomes a suspect which may include a scenario where the pre-trial stage is over. Moreover, the procedural guarantees on this issue vary considerably in the Member States of the EU as some states obligate the prosecutor to inform the suspect as soon as the person is investigated or suspect of having committed a crime, ${ }^{125}$ while other states have more discretion in determining the moment when the person is designated as a suspect, usually objectively ascertainable in official interviews or interrogations or the application of coercive measures against the person.

As the EDP's acts may include investigative measures against an individual with the goal of seeking reasonable grounds for filing a charge against the person, the EDP is engaged in both the investigative and prosecution stages. In this manner, the investigative stage does play a crucial role for the outcome of the criminal procedure and the well-established standard of the ECHR jurisprudence might be a guiding authority:

"The investigation proceedings are of great importance for the preparation of the trial because they determine the framework in which the offence charged will be considered at the trial. Furthermore, it cannot be excluded that evidence obtained in the investigating proceedings will be relied on in the judgment." ${ }^{126}$

Hence, when defense rights are concerned, the basis for activity affecting the rights of the defense can be identified already at the investigative stage.

Nonetheless, the manner in which, for example, Article 6(3)(c) guarantees are applied and upheld in the pre-trial stage and during preliminary investigations depends on the specificities of the proceedings at issue and on the particular circumstances of the case. This is because "the evidence obtained during this stage often determines the framework in which the offence charged will be considered at the trial and national laws may attach consequences to the attitude of an accused at the initial stages of police interrogation which are decisive for the prospects of the defense in any subsequent criminal proceedings. An accused may therefore find himself in a particularly vulnerable position at that stage of the proceedings, the effect of which may be amplified by increasingly complex legislation on criminal procedure, notably with respect to the rules governing the gathering and use of evidence." ${ }^{127}$

Moreover, there is an argument that EU judicial review should be applicable to acts and decisions based on EU law and national review must apply to acts and decisions

124 Fotiv. Italy [1982] 5 EHRR 313, para. 52.

125 Novokmet provides the examples with Article 50 of StPO of Austria. See Novokmet,

"The European Public Prosecutor's Office and the Judicial Review," 392.

126 Can v. Austria, European Commission of Human Rights (July 12, 1984) no. 9300/81, para. 5 O.

127 Ibrahim and others $v$. the UK, app. No. 50541/o8 (GC ECtHR judgment of September 13, 2016), para 253. See also, Imbrioscia v. Switzerland (ECtHR judgment of November 24, 1993), para 38. 
based on national law. However, such an approach may dilute the principle of legal certainty. Furthermore, it may create unnecessary complications in the delimitation of what constitutes legal bases in EU or national laws. ${ }^{128}$ The teleological argument here rests on the structure of the EPPO is an EU body in what could be labeled a single EU judicial area. Hence, the legal effects of the EPPO at any stage of its work may be seen as potentially interfering with fundamental rights under the CFR and ECHR mechanisms, thus meriting a possibility for a three-part judicial review on supranational, domestic and/or regional levels. ${ }^{129}$

The relationship between the EPPO and the EU Member States who do not participate in the framework, such as Poland and Hungary, would be regulated via a cooperative mechanism, particularly with regards to the exchange of strategic information, secondment of EPPO offices, or notification by the Member States on matters of judicial cooperation in criminal matters with respect to cases within the EPPO competence vis-à-vis Member States who do not participate in the EPPO enhanced cooperation framework. ${ }^{130}$ Such a cooperation is rather limited but could be aided by the functions of Eurojust, OLAF or Europol cooperation. ${ }^{31}$ The rejection by Poland and Hungary to participate in the EPPO does not contribute to the efforts to reverse the backsliding of democracy and the problems with the rule of law. The EP specifically reminded in its Article 7(1) TEU Proposal that "Hungary decided not to participate in the establishment of the European Public Prosecutor's Office responsible for investigating, prosecuting and bringing to judgment the perpetrators of, and accomplices to, criminal offences affecting the financial interests of the Union." ${ }^{132}$ In this manner, the EP outlines the political and systemic corruption affecting the financial interests of the Union as the axis which connects to the problems with fundamental values and rule of law. As seen above, the complex structure of the EPPO could have been used to alleviate the backsliding to some degree with the intricate interplay of supranational and domestic judicial and prosecutorial actors, especially in the case of Hungary as emphasized in the EP's Article 7(1) TEU proposal. This could be seen as a missed opportunity by the two states to take positive steps to bolster the rule of law although the pending issue is to what degree the EPPO structure could have been effective in these states where the capture and restructuring of the judiciary have significantly undermined the independence of the judiciary and separation of powers. ${ }^{133}$ Through the unwillingness to participate in the EPPO as another missed opportunity in Hungary and Poland, one can discern the pattern of the interconnectivity of regression of the rule of law,

128 Mitsilegas and Giuffrida, "Raising the Bar?," 14.

129 Valsamis Mitsilegas, EU Criminal Law after Lisbon (Oxford: Hart Bloomsbury, 2016). 116.

130 Article 105 of Regulation 2017/1939.

131 See Articles 100, 101 and 102 of Regulation 2017/1939.

132 European Parliament, "Hungary Proposal under Article 7(1) TEU," 12.

133 See StoyanPanov, "Tales of Separation of Powers: The Effect of Populism on the Rule of Law, Separation of Powers and Judicial Independence in Hungary and Poland" in Populism, Nationalism and Human Rights, ed. J. Vidmar (Brill/Nijhoff, forthcoming). 
protection of the fundamental values of the EU and systemic and political corruption. The conceptual bind can be inferred from what is not taking place in order to diminish the attempts on EU and domestic levels to respond to the deficiency in the rule of law and regression in anti-fraud, anti-corruption mechanisms.

\section{The Protection of EU's Budget in Case of Rule of Law Deficiencies}

The European Commission has been active in another aspect related to the protection of the rule of law and financial interests of the EU. In May 2018, the Commission issued a proposal for a Regulation for the Protection of the EU's Budget in Case of Deficiencies of the Rule of Law in the EU Member States. The Commission outlines that the EU is a community of law, and EU values reflected in various policies include "the EU budget, where respect for fundamental values is an essential precondition for sound financial management and effective EU funding." ${ }^{134}$ The rule of law is "the backbone of any modern constitutional democracy" in all EU Member States as enshrined in the Preambles of the TEU and the Charter of Fundamental Rights and Article 2 TEU. ${ }^{135}$ The link between the rule of law and the financial interests of the Union is that the former is a prerequisite for the confidence of EU spending. The proposed Regulation is to enter into force on January 1, 2021.

The main reason for the proposal is the recent backsliding in domestic checks and balances in cases such as Hungary and Poland. Such regress has resulted in generalized weaknesses in the rule of law protections in some Member States which is a serious concern for the whole Union. The proposal allows the EU institutions to complement the existing mechanisms such as the criminal-law-oriented EPPO in order to ensure effective control and respect of the rule of law and protect the EU's financial interests. In this manner, when the financial loss is caused by the generalized rule of law problems in member states, "the European Union should be granted the possibility to adopt appropriate measures." ${ }^{136}$

Special emphasis is placed on the independence of the judiciary with specific guarantees for non-interference, absence of hierarchical constraints or subordination to other political bodies, and protection against "external interventions or pressure liable to impair the independent judgment of its members or influence their decisions." 137 The cornerstones behind such measures are the principles of transparency and proportionality as well as consistency with existing Treaty provisions such as Article 2 TEU and other EU policies like the protection of the financial interests of the Union

134 Proposal for a Regulation of the European Parliament and of the Council on the Protection of the Union's Budget in Case of Generalized Deficiencies as regards the Rule of Law in the Member States (May 2, 2018) $\operatorname{COM}(2018) 324$ final, 1. 
under the EPPO framework. The rule of law demands that public powers remain constrained by the law, based on democratic values, protection of fundamental rights and control by an independent and impartial judiciary as the principle is fundamental for the respect of the principles of legality and legal certainty, separation of powers, and the prohibition of arbitrariness of executive powers. ${ }^{138}$

The legal basis of the proposed Regulation is under the Financial Provisions heading of the TFEU, namely Article $322(1)$ (a) of the TFEU which stipulates that the Parliament and the Council according to the ordinary legislative procedure shall adopt regulations on the financial rules about establishing and implementing the Union budget. The rules are for the protection of the EU's budget in cases of generalized deficiencies as regards the rule of law in the Member States. ${ }^{139}$

Generalized deficiencies are defined in Article 2 of the proposed Regulation as "a widespread or recurrent practice or omission, or measure by public authorities which affects the rule of law." The identification of the generalized deficiencies is qualitative in nature and performed by the Commission, based on information of all available sources and institutions such as EU or domestic judiciaries. ${ }^{140}$ The generalized deficiencies particularly affect the rule of law when such endanger the independence of the judiciary, fail to prevent, correct and sanction arbitrary or unlawful decisions by public authorities or fail to ensure the absence of conflicts of interests, or limit "the availability and effectiveness of legal remedies." 141 The measures include government entities which encompass "all public authorities at all levels of government, including national, regional and local authorities." ${ }^{142}$

The measures for a generalized deficiency of the rule of law in a Member State are to be taken when the deficiency "affects or risks affecting the principles of sound financial management or the protection of the financial interests of the Union." ${ }^{143}$ The particular focus of the risk or the effect is:

a) on the proper functioning of the authorities of the Member State implementing the Union budget, especially in the context of public procurement;

b) The proper functioning of investigation and public prosecution services as regards the prosecution of fraud, corruption or other breaches of EU law related to the implementation of the EU budget;

c) The effective judicial review by independent courts for the above functions;

d) The prevention and sanctioning of fraud, corruption or other breaches of EU law related to the EU budget and the imposition of effective and dissuading penalties;

e) The recovery of unduly paid funds;

138 See preamble 2 of Proposal COM (2018) 324,. See also, C-46/87 and 227/88 Hoechts (ECJ judgment of September 21, 1989), para. 19.

139 Article 1 of Proposal COM (2018) 324.

140 Preamble 12 of Proposal COM (2018) 324.

141 Article 3(2)(a-c) of Proposal COM (2018) 324.

142 Article 2(b) of Proposal COM (2018) 324.

143 Article 3(1) of Proposal COM (2018) 324. 
f) And the effective cooperation with OLAF and the EPPO in their investigations and prosecutions under the guise of the principle of loyal cooperation. ${ }^{144}$

The financial interests of the Union are protected if the public authorities in the Member States act in good faith and in accordance with the law and when breaches occur, such are effectively investigated and prosecuted, subject to judicial review of independent national courts and the CJEU. ${ }^{145}$

The procedure of the conditions for the measures in Article 3 of the proposed Regulation is based on the initial assessment of the Commission on a standard of review of "reasonable grounds to believe." 146 A notification is sent to the Member State, in which the Commission sets out the grounds of the findings. The notification indicates the time in which the Member State can provide the relevant information and relay its observations to the Commission, "which shall be no less than 1 month from the date of notification of the finding." ${ }^{147}$ The observation serves as the opportunity for the Member State to propose remedial measures as regards the deficiencies.

In the next step, the Commission evaluates the information and the observations of the Member State, "when deciding whether or not to submit the proposal for a decision on the appropriate measures." 148 The Commission has full discretion as to the determination if the generalized deficiency is present and this is squarely in light of the role of the Commission as the watchdog of EU interests. In this part, the mechanism resembles the infringement proceedings under Article 258 TFEU as the Commission is the guarantor and enforcer of EU obligations vis-a-vis the Member States. In this manner, "the Commission first tries to persuade the member to change its policy" that is in an alleged breach of EU law and then "the Commission submits a reasoned opinion in which the violation is identified and a change of policy is requested." 149 Albeit the proposal for an implementing act of the appropriate measures along with the observations of the Member State(s) under the framework at hand resembles the reasoned opinion, the Commission submits it to the Council and not to the CJEU.150 The proposal decision of the Commission for the implementing measures is deemed to be adopted by the Council if the Council does not reject by qualified majority the Commission's proposal within one-month period. ${ }^{151}$ Although the role of the Council in this stage is reactive, still the central tenet is the intergovernmental aspect of decisionmaking. Moreover, the Council possesses the power to amend the Commission's proposal and adopt its decision as regards the implementing measures by a qualified

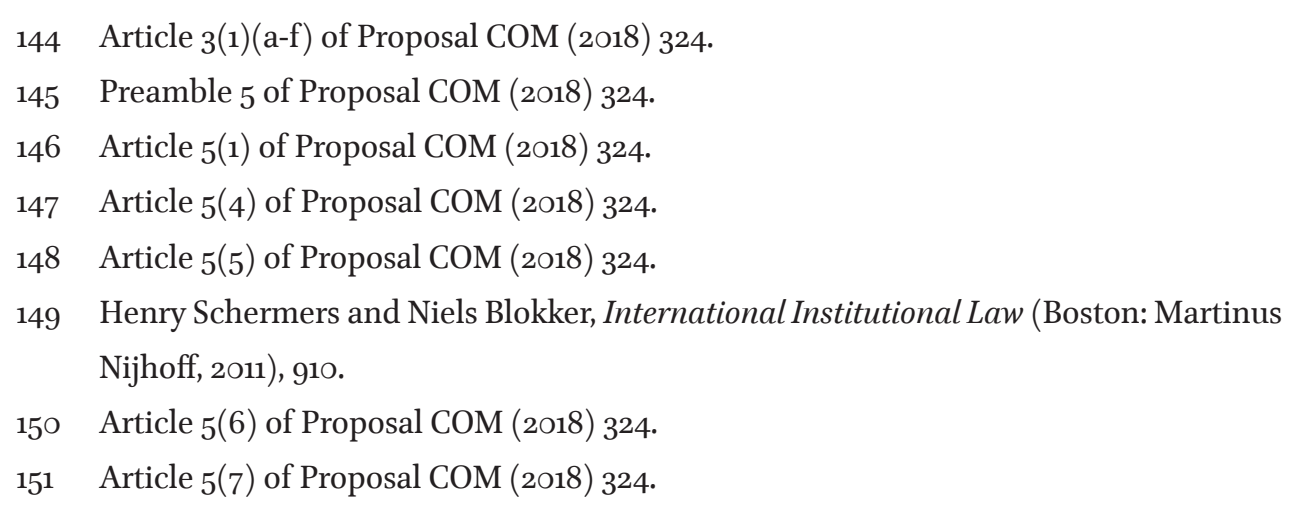


majority. ${ }^{152}$ In this manner, the interests of the Member States are represented at the most delicate stage of the decision-making process. In terms of democratic legitimacy, the Commission is under an obligation to inform immediately the European Parliament as regards the implemented measures and the procedure of implementation. ${ }^{153}$

There are two main types of measures that could be implemented against the generalized deficiency in Member States. If the Commission implements the EU budget in direct or indirect management under Article 62(a) and (c) of the Financial Regulation and where the government entity is the recipient, the measure is the suspension of payments or a prohibition to enter into new legal commitments. ${ }^{154}$ In cases where the Commission implements the EU budget in a shared management according to Article 62(b) of the Financial Regulation, the Commission has six options: suspension of the approval of one or more programs, suspension of commitments, reduction of commitments, reduction of pre-financing, interruption of payment deadlines, and suspension of payments. 155 The leading principle of the choice of the appropriate measure is that the measure shall be "proportionate to the nature, gravity and scope of the generalised deficiency as regards the rule of law"156 along with the degree of cooperation of the concerned Member State and effects on the EU's budget.

The proposed Regulation includes the procedure for lifting the implemented measures. The Member State has the onus to submit evidence to the Commission that shows that the generalized deficiency as regards the rule of law "has been remedied or has ceased to exist." 157 Then the Commission is tasked with assessing the situation and if the assessment is favorable for the Member State, the Commission submits to the Council a proposal for lifting the measures in full or in part. The procedure set in Article 5(2-7) of the proposed Regulation is applicable and the measure is lifted if "the situation leading to the imposition of those measures has been sufficiently remedied." 158

In early 2019, the European Parliament supported the Commission's proposal with an overwhelming 397 in favor to 158 MEPs against with 69 abstentions. The voting pattern was based on a division between the East-West with MEPs from Central and Eastern Europe voting against, over their political party affiliations, along with more Eurosceptic MEPs. ${ }^{159}$

A few problems could be noted as regards the proposed Regulation besides the decision-making process of the framework outlined above. One issue with the proposed

$15^{2}$ Article 5(8) of Proposal COM (2018) 324.

153 Article 7 of Proposal COM (2018) 324.

154 Article 4(a)(1-2) of Proposal COM (2018) 324.

155 Article 4(b)(1-6) of Proposal COM (2018) 324.

156 Article 4(3) of Proposal COM (2018) 324. See also, Preamble (14).

157 Article 6(1) of Proposal COM (2018) 324.

158 Article 6(2) of Proposal COM (2018) 324. See also, Preamble (17).

159 Lili Bayer, "European Parliament Backs Plan to Link EU Funds to Rule of Law,"

Politico, January 17, 2019, accessed December 23, 2019, https://www.politico.eu/article/budget-

hungary-poland-rule-of-law-european-parliament-backs-plan-to-link-eu-funds/. 
mechanism is teleological. Under the proposed framework, payments that originate from the Cohesion Policy may be affected in Member States with deficiencies in the rule of law. The Cohesion Policy "has been used to provide support for the poorer regions of Europe and stabilise their economies with a view to promoting growth, employment and sustainable development." 160 Approximately 34\% of the EU budget for the 2014-2020 period has been allocated for economic, social, and territorial cohesion. ${ }^{161}$ Additionally, the funds may finance various environmental and transportation-related projects. The purpose behind the Cohesion Policy is the promotion of sustainable growth in the less developed regions of the EU.162 Although the allocation method for the Cohesion funds is still primarily based on the GDP per capita in the Member State's region, other relevant criteria are to be taken into consideration such as levels of youth unemployment and education, climate change, and more importantly for the purpose of the rule of law, the reception and integration of migrants. ${ }^{163}$ The new framework would allow for a mid-term review incorporating budgetary flexibility to determine if changes are necessary for the last two years of the funding period. Most importantly, the proposed MFF introduces an annual performance review, based on a dialogue between the Commission and the relevant domestic authorities with implementation date provided every two months by Member States.

A possible suspension of payments under the proposed mechanism may lead to detrimental effects of what Cohesion Policy, including the European Regional Development Fund, European Social Fund, and the Cohesion Fund, aims at. Based on the numbers of allocated funds under the European Structural and Investment Funds, Member States like Poland, Italy, Romania, Spain, Hungary and Czechia could be particularly affected by payment suspensions as they benefit the most from the funds in nominal value, while in terms of EU's net spending as percentage of the GNI of the Member State, Estonia, Latvia, Lithuania, Bulgaria, Hungary and Poland would be particularly affected as in some cases the EU budget expenditures in these member

16o “Cohesion Fund," European Commission, accessed June 6, 2o19, https://ec.europa.eu/regional_ policy/en/policy/what/glossary/c/cohesion-fund.

161 "EU Budget," European Commission, accessed June 6, 2019, https://europa.eu/european-union/ about-eu/eu-budget/expenditure_en.

162 For the 2021-2027 Multiannual Financial Framework period, there are five main objectives of the Regional Development and Cohesion Policy: smarter Europe through innovations, digitization, support for small and medium-sized enterprises; a Greener and carbon-free Europe with focus on energy transition, renewables and fight against climate change; a Connected Europe based on the development of strategic transport and digital networks; a Social Europe supporting quality employment, education, social inclusion, skills building and equal access to healthcare; and a Europe closer to the citizens with emphasis on locally-led development strategies and sustainable urban development.

163 "New Cohesion Policy," European Commission, accessed June 6, 2019, https://ec.europa.eu/ regional_policy/en/2O21_2O27/. 
states vary between 3 and $5 \%$ of their GNI. ${ }^{164}$ However, the effect of the suspension would depend on the determination of the Commission and the Council with regards to the programs and relevant funds. If the breaching Member State is not dissuaded to correct the rule of law deficiencies by the imposed sanction to tap in the Cohesion Policy in the future, the effect of the sanction may be symbolic. As the proportion of the EU Cohesion Policy funds is not significant in comparison to the overall GDP levels in most Member States, the sanction could be perceived as more inflicting on the reputation of the Member States in terms of naming and shaming. Nonetheless, the rule of law mechanism offers a leverage to the EU to respond to rule of law backsliding coupled with systemic corruption or PIF offences in Member States which otherwise would be only prone to pressure and/or sanction under the Article 7 TEU proceedings.

\section{Conclusion}

This article seeks to identify and analyze three key existing and prospective mechanisms that the EU can utilize in its efforts to respond to the rule of law problems and systemic, political corruption in EU Member States. As seen above, the task is complex in light of the multi-level EU institutional and legal structure in order to evaluate appropriately the impact of the trifecta mechanisms on member state-level rule of law and corruption. The focus of analysis is thus placed on the protection of fundamental values of the Union, including the rule of law and human rights, as well as a more in-depth examination of the more criminal law-oriented regime of the EPPO that may affect political or societal issues of corruption. In this manner, the intricate puzzle of law and politics is analyzed in order to reflect upon what the EU has in its toolshed in order to counteract the intersection of corruption and the protection of the rule of law. As all mechanisms are novel and have not been used extensively in comparison to the infringement proceedings, it is important to closely follow their function and effectiveness as enforcement frameworks. For example, the working practices, effectiveness and efficiency of the EPPO mechanism are to be evaluated every five years by the Commission. This will be the chance, if necessary, for any amendments that need to be introduced in order to strengthen and improve the EPPO framework, especially when the topics concern the judicial review and the complex interaction of the structure of the EPPO. ${ }^{165}$ As for the proposed mechanism for deficiencies in the rule of law and suspension of EU funds, it is pertinent to follow whether the Member States would be willing to support the Commission's proposal in its current form. The structure of the proposed mechanism is designed to allow the Commission to react more swiftly to deficiencies in the rule of law and to potentially apply specific

164 “Overview of European Structural and Investment Funds," European Commission, accessed June 6, 2019, https://cohesiondata.ec.europa.eu/overview. See also, "EU Budget 2017- Financial Report," European Commission, 37, accessed June 6, 2019, http://ec.europa.eu/budget/library/ biblio/publications/2018/financial-report_en.pdf.

165 See Article 119(2) of Regulation 2017/1939. 
sanctions in a more timely manner than the Article 7 TEU mechanism. It has been almost two years since the Commission triggered the Article 7(1) TEU mechanism in the case of Poland. The Article 7 TEU mechanism also remains to be evaluated as to whether it would achieve the results of convincing Hungary and Poland to return to their obligations under Article 2 TEU as regards the rule of law and other fundamental values of the Union. More pertinent remains the issue of how the triad of mechanisms would be used in future cases concerning corruption and the rule of law. The EU seems still to be in the testing territory but regressive developments throughout Europe with regards to the rule of law, corruption, or backsliding of democracy indicate that soon the mechanisms may need to be applied in a timely manner.

\section{Bibliography}

Albors-Llorens, Albertina. "Remedies against the EU Institutions after Lisbon: An Era of Opportunity?" Cambridge Law Journal 71, no. 3 (2012): 507-36.

Bayer, Lili. "European Parliament Backs Plan to Link EU Funds to Rule of Law." Politico. Accessed January 17, 2019. https://www.politico.eu/article/budget-hungarypoland-rule-of-law-european-parliament-backs-plan-to-link-eu-funds/.

Benvinisti, Eyal. The Law of Global Governance. The Hague Academy of International Law, 2014.

Bianchi, Andrea. International Law Theories. Oxford University Press, 2016.

Can v. Austria, European Commission of Human Rights (July 12,1984) no. 930o/81.

Case C-46 and 48/93 Brasserie du Pêcheur [1996] ECR I-1029.

C-46/87 and 227/88 Hoechts (ECJ judgment of September 21, 1989).

Case C-5o/ooP, Union de Pequenos Agricultores (UPA) v. Council [2002] ECR I-6677.

Case C-68/88 Commission v Greece [1989] ECR 1-2965.

Case C-188/92 TWD [1994] ECR I-833.

Case C-224/o1 Gerhard Köblerv. Republik Österreich [2003] ECR I-10239.

Case C-352/98P Bergadem [2000] ECR I-5291.

Cases C-463/10 P and C-475/10 P Deutsche Post and Germany v. Commission [2011] ECR I-9639.

Case C-583/11 P Inuit ECLI: EU: C:2013:625.

Case T-193/o4 Hans-Martin Tillackv. Commission [2006] ECR II-3995.

Corigliano v. Italy, App. no. 8304/78 (ECtHR Judgment of December 10, 1982).

Council Regulation (EU) 2017/1939, OJ L283 (October 12, 2017).

Delmas-Marty, Mirelles, and J. R. Spencer, eds. European Criminal Procedures. (Cambridge: Cambridge University Press, 2002).

Deweerv. Belgium [1980] 2 EHRR 239.

Dvorskiv. Croatia, App. No. 25703 (ECtHR Judgment of October 20, 2015).

Erkelens, Leendert, Arjen Meij, and Marta Pawlik, eds. The European Public Prosecutor's Office. An Extended Arm or a Two-Headed Dragon? (Hague: T. M. C. Asser Press \& Springer-Verlag, 2015).

EU Directive 2017/1371, L198/29 (July 5, 2017). 
European Commission, "Article 7 of the Treaty on European Union-Respect for and promotion of the values on which the Union is based." $\operatorname{COM}(2003) 606$ final.

European Commission. "Cohesion Funds." Accessed June 6, 2019. https://ec.europa.eu/ regional_policy/en/policy/what/glossary/c/cohesion-fund.

European Commission. "EU Budget." Accessed June 6, 2019. https://europa.eu/ european-union/about-eu/eu-budget/expenditure_en.

European Commission. "EU Budget 2017- Financial Report." Accessed June 6, 2019. http://ec.europa.eu/budget/library/biblio/publications/2018/financial-report_ en.pdf.

European Commission. "New Cohesion Policy." Accessed June 6, 2019. https://ec.europa. eu/regional_policy/en/2021_2027/.

European Commission. "Overview of European Structural and Investment Funds." Accessed June 6, 2019. https://cohesiondata.ec.europa.eu/overview.

European Commission, "Proposal for a Regulation of the European Parliament and of the Council on the Protection of the Union's Budget in Case of Generalised Deficiencies as regards the Rule of Law in the Member States." (May 2, 2018) COM (2018) 324 final.

European Parliament, "Establishing of an EU Mechanism on Democracy, the Rule of Law and Fundamental Rights." Accessed June 6, 2019. http://www.europarl. europa.eu/legislative-train/theme-area-of-justice-and-fundamental-rights/fileeu-mechanism-on-democracy-the-rule-of-law-and-fundamental-rights.

European Parliament, "Resolution of 14 November 2018 On the Need for A Comprehensive EU Mechanism for the Protection of Democracy, The Rule Of Law And Fundamental Rights." 2018/2886(RSP) (November 14, 2018).

European Parliament, "Report on a Proposal Calling on the Council to Determine, Pursuant to Article 7(1) of the Treaty on European Union, the Existence of a Clear Risk of a Serious Breach by Hungary of the Values on Which the Union is Founded." (2017/2131 (NL)) Committee on Civil Liberties, Justice and Home Affairs (July 4, 2018).

Fotiv. Italy [1982] 5 EHRR 313.

Giuffrida, Fabio. "The European Public Prosecutor's Office: King without Kingdom?"

Ibrahim and others $v$. the UK, App. No. 50541/o8 (GC ECtHR Judgment of September 13, 2016).

Imbrioscia v. Switzerland (ECtHR Judgment of November 24, 1993).

Kingsbury, Benedict, Nico Krisch, Richard Stewart and Jonathan Weiner, "Global Governance as Administration- National and Transnational Approaches to Global Administrative Law." Law and Contemporary Problems 68, (Summer 2005): 1-13.

Klabbers, Jan, Anne Peters, and Geir Ulfstein, eds., The Constitutionalization of International Law. (Oxford: OUP, 20o9).

Kochenov, Dmitry. "Busting the Myths Nuclear: A Commentary on Article 7 TEU." EUI Working Papers Law 2017/10 (2017):1-13. 
Kochenov, Dmitry, and Laurent Pech. Better Late than Never? On the European Commission's Rule of Law Framework and its First Activation." Journal of Common Market Studies 24 (July 2016): 1062-74.

Ligeti, Katalin, and Michele Simonato, "The European Public Prosecutor's Office: Towards a Truly Prosecution Service?" The New Journal of European Criminal Law 4, no. 1-2 (2013).

Micallef v. Malta, App. no. 17056/o6, (GC ECtHR Judgment of October 15, 2009).

Mitsilegas, Valsamis, and Fabio Giuffrida, "Raising the Bar? Thoughts on the Establishment of the European Public Prosecutor's Office." CEPS Policy Insight No. 2017-39 (November 30, 2017): 1-21.

Novokmet, Ante. "The European Public Prosecutor's Office and the Judicial Review of Criminal Prosecution." New Journal of European Criminal Law 8, no. 3 (2017): 374-402.

Panov, Stoyan. "Judicial Anti-Corruption Reforms in Bulgaria and the Rule of the EU in Bulgaria's Judiciary Regulation.” Südosteuropa 61, no. 2 (2013): 193-218.

Panov, Stoyan. "The Obligation Aut Dedere Aut Judicare('Extradite or Prosecute') in International Law." PhD diss., University of Birmingham, 2016.

Pech, Laurent. 'AA Union Founded on the Rule of Law': Meaning and Reality of the Rule of Law as a Constitutional Principle of EU Law" EU Constitutional Law Review 6, (2010).

Peers, Steven, and Mario Costa. "Court of Justice of the European Union Judicial Review of EU Acts after the Treaty of Lisbon" European Constitutional Law Review 8, no. 2 (2012): 82-104.

Pelissier and Sassiv. France, [2000] 30 EHRR 715.

Peters, Anne. "Compensatory Constitutionalism: The Function and Potential of Fundamental International Norms and Structures." Leiden Journal of International Law 19, (January, 2006): 579-610.

Rosas, Allan, and Lorna Armati. EU Constitutional Law: An Introduction. Hart 2012.

Sadurski, Wojciech. "Adding a Bite to a Bark? A Story of Article 7, the EU Enlargement and Jörg Haider," Columbia Journal of European Law 16 (2010).

Schermers, Henry, and Niels Blokker. International Institutional Law. (Leiden, Boston: Martinus Nijhoff, 2011).

Tsagouris, Nicolas, ed. Transnational Constitutionalism: International and European Perspectives. (Cambridge: Cambridge University Press, 2007).

Vera Fernández-Huidobro v. Spain, App. no. 74181/o1 (ECtHR Judgment of January 6, 2010).

Von Bogdany, Armin, and Michael Ioannidis. "Systemic Deficiency in the Rule of Law: What It Is, What Has Been Done, What Can Be Done." Common Market Law Review 51, no. 1 (2014): 59-96.

Weiler, Joseph, and Marlene Wind, eds. European Constitutionalism beyond the State. (Cambridge: Cambridge University Press, 2003). 
Response to the Challenges to the Rule of Law and Corruption

Weyembergh, Anne, and Chloe Brière, “Towards a European Public Prosecutor's Office (EPPO)." European Parliament, Civil Liberties, Justice and Home Affairs (2016): $1-57$.

(2)

Stoyan Panov is a lecturer of International Law and Jurisprudence at University College Freiburg, University of Freiburg. He has received his education at University of Birmingham, Leiden University, Georgetown University, and DePauw University. Stoyan Panov has research interests in the areas of EU Law, International Human Rights Law, International Criminal Law, Public International Law, the Rule of Law, Anti-Corruption Law, and International Security. 